\title{
Detection of Soil Salinity for Bare and Cultivated Lands Using Landsat ETM+ Imagery Data: A Case Study from El-Beheira Governorate, Egypt
}

\author{
Emad Fawzy Abdelaty*, Emad Farouk Aboukila1
}

\begin{abstract}
Soil salinization is a standout amongst the most basic environmental universal issues due to its adverse effects on agricultural productivity and sustainable development. Remote sensing is an important tool for investigating soil characteristics such as soil salinity. In saline soils, the spectral reflectance of salt at the surface or of vegetation execution that was adversely influenced by salt varies with different salinity levels. So, many salinity and vegetation indices have been developed and used. This study used ground data and Landsat Enhanced Thematic Mapper Plus (ETM+) satellite images (visible and near-infrared reflectance) to compare between eleven spectral indices, which encompassed soil salinity and vegetation indices, to determine the best index to the estimations of soil salinity for bare and cultivated soil. Soil samples were gathered from two locations in El-Beheira governorate in Egypt; 24 samples from Wadi-El-Natroun (bare soil) and 22 samples from El-Bostan (cultivated soil) and the soil samples locations were overlaid on ETM+ satellite image to extract the exact index values. The electrical conductivity (EC) measured in saturated soil-paste extract. Among those spectral indices, SI3 showed the highest correlation coefficient with $E C\left(R^{2}=0.77\right)$ according to linear regression analysis and $\mathrm{S} 6$ according to Polynomial regression $\left(R^{2}=0.83\right)$, followed by $S 3$ for bare soil. NDVI and SAVI get the best result for assessing the soil salinity of cultivated soil $\left(R^{2}=0.83\right.$ and 0.76$)$ according to Polynomial and linear regression, respectively, followed by RVI.
\end{abstract}

Keywords: Soil salinity, salinity indices, vegetation indices, remote sensing.

\section{INTRODUCTION}

Soil salinization, either naturally occurring (primary soil salinization) or human-induced (secondary soil salinization) is a global vital issue, like climate change, global warming, desertification, and other environmental issues (Rowel, 1994). According to Farifteh (2007) soil salinization, as a term, that refers to the accumulation of salts on the surface or/and at the root zone of the soil and causes harmful effects on both of plants and soil. It hurtfully influences the soil productivity, therefore undermining the sustainability of agricultural production (Rowel, 1994) and if it increases in the future with its present rate, a lot of nations will confront a big problem of producing enough food for their population (Gorji et al., 2017). It reduces the area of cultivated land from 1 to $2 \%$ per year and continues to increase (FAO, 2002). Therefore, the monitoring and predicting of soil salinity are essential to take protective measures against further degradation of the soil (Gorji et al., 2015).

In some countries such as Argentina, Egypt, India, Iraq, Pakistan, Syria and Iran, the land salinization is a serious issue due to its harmful effects on the national economy (Rhoads, 1990). The saline soils are common in regions under semi-arid and arid climate conditions, but it may occur in any region and under every climate condition in the world (Al-Khair, 2003).

The saline soils represent about 397 million hectares of land around the world, according to the Food and Agriculture Organization (Koohafkan, 2012). The Egyptian government has an increasing demand for selfsufficiency of agricultural products, so it is working hard to reclaim new lands (Varallyay, 1987) for providing sufficient food for its rapidly increasing population (Gorji et al., 2017). Soil salinization in such lands hinders the governments' plans for agriculture expansion (Varallyay, 1987).

According to Gehad (2003), nearly $55.44 \%$ of the Egyptian soil is non- saline, $5.34 \%$ moderately saline, $7.23 \%$ high saline, $5.1 \%$ very high saline, $0.32 \%$ towns, $26.47 \%$ water bodies and $0.1 \%$ could be considered as swamps.

Traditionally, soil salinization is measured and monitored by wet chemistry laboratory method, this method needs more time and has a high cost and unsuited for large areas. Therefore, in recent times, remote sensing and GIS are among cheaper and faster methods, also covers large areas (Mashimbye, 2013). Those Modern technologies such remote sensing and

\footnotetext{
${ }^{1}$ Assistant Professor, Department of Natural Resources and Agricultural Engineering, Faculty of Agriculture, Damanhour University, Damanhour, Egypt

E-mail address: emad.fawzy@damanhour.edu.eg (E.F. Abdelaty), emad@damanhour.edu.eg (E.F. Aboukila)

*Corresponding Author: Emad F. Abdelaty. Faculty of Agriculture, Damanhour University, Al Abadia Campus, Damanhour, P.O. Box 22516, Egypt. Phone: +2 01225023534, Fax: +20453282303 , Email: emad.fawzy@damanhour.edu.eg Received September 10,2017, Accepted September 30, 2017.
} 
GIS make the measuring and monitoring of soil salinity quite controllable and manageable (Gorji et al., 2015), but they require skilled people in field observation techniques (Soil Science), geographic information systems (GIS), remote sensing and geostatistical techniques (Mashimbye, 2013).

Soil salinity can be detected from remote sensing data through two approaches; directly by analyzing the spectral reflectance of soils on bare soil, with salt efflorescence and crust (salinity indices), or indirectly through analyzing the spectral reflectance of a growing vegetation on affected soils (vegetation indices) (AlKhair, 2003; Aldakheel, 2011; Mashimbye, 2013; Matinfar, 2013).

Many researchers (Katawatin and Kotrapat, 2004; Mehrjardi et al., 2008; Yu et al., 2010; Mulder et al., 2011) have investigated the utility and effectiveness of ETM + data for soil salinity mapping and monitoring. The aim of this research is to study how the different remote sensing indices (salinity and vegetation indices), which are derived from Landsat ETM+ satellite image, work on soil salinity prediction of both bare and cultivated lands in the study area compared to laboratory measurements of electrical conductivity.

\section{MATERIALS AND METHODS}

\section{Study Area}

In this research two study areas, Wadi-El-Natroun (Location 1) and El-Bostan farm (Location 2), were chosen; all of them are located in north Egypt (ElBeheira Governorate): Location 1 presents bare lands and lies between longitude 222083 to $223433 \mathrm{E}$ and latitude 3362575 to $3363798 \mathrm{~N}$. Whereas location 2 presents cultivated lands (wheat and clover) and lies between longitude 258991 to $259639 \mathrm{E}$ and latitude 3404715 to $3405468 \mathrm{~N}$ (Fig. 1)

El-Beheira Governorate is located under arid conditions; the mean annual precipitation ranges from 9.6 to $24.8 \mathrm{~mm}$ month $^{-1}$ falling in the months of November through February. The values of mean annual temperature and relative humidity are $21{ }^{\circ} \mathrm{C}$, and $57 \%$ respectively (Ebaid et al., 2016).

\section{Remote Sensing and GIS}

Landsat 7 images have three visible bands (blue, green, and red), 1 near infrared band (NIR), and 2 shortwave infrared bands (MIR-1, MIR-2) at $30 \mathrm{~m}$ resolution; a thermal infrared band (TIR) at $60 \mathrm{~m}$ resolution; and a panchromatic (PAN) band with $15 \mathrm{~m}$ resolution. The Landsat 7 image was acquired in March 2017 and was also resampled to $30 \mathrm{~m}$ resolution (Fig. 2). The coordinate system has UTM projection, WGS 1984 datum, and The UTM zone is 36 northern. The image indices have been derived and tested by using
ERDAS (10.1) and ENVI (5.3) software. All the created image indices have been registered and loaded as input data to ArcGIS 10.2 software as an information layer.

\section{Field Work and Laboratory Analysis}

A hard and soft copy of ETM+ image, which was taken on March 2017, was used for choosing the location of sampling points. The exact position of sampling points in latitude and longitude was identified by GPS (Global Positioning System) (Table 1).

The positions of soil samples were chosen according to a systematic random method for location 1 (Wadi-ElNatroun) and according to the homogeneity of crop growth in location 2 (El-Bostan farm) (Fig. 1). Forty-six samples were collected from the upper layer $(0-30 \mathrm{~cm})$ by an auger. Of the 46 soil samples collected, 24 were collected from location 1 and 22 were collected from location 2. Each sample was air dried, ground, sieved with a 2-mm sieve and stored in a plastic bag until analysis. The EC of the saturated paste of each sample was determined using the methods outlined by Jackson (1973).

\section{Remote Sensing Spectral Indices}

Eleven spectral indices were generated from two different remote sensing indicators, salinity and vegetation (Table 2). Four vegetation and seven soil salinity indices that were derived from the ETM+ images were examined based on their potential for assessing soil salinity. Both soil samples and remote sensing data were acquired during March 2017. Fortysix soil samples were then overlaid on ETM+ images to extract the exact index values related to the soil samples

\section{Statistical Analysis}

Two different approaches; namely, linear regression analysis and polynomial regression analysis have been conducted to establish a relationship between EC laboratory measurements and satellite image-derived indices using the SPSS software (SPSS, 2007).

\section{RERSULTS AND DISCUSSION}

\section{Laboratory Electrical Conductivity (EC)}

The salinity was classified into five classes using EC values according to the Food and Agriculture Organization (FAO) soil salinity classification system (Abrol et al., 1988) as shown in Table 3. The EC values of the study area ranged from non-saline to strongly saline $\left(1.11-9.50 \mathrm{dS} \mathrm{m}^{-1}\right)$ at location 1 , and ranged from non-saline to moderately saline $(1.00-$ at $6.38 \mathrm{dS}$ $\mathrm{m}^{-1}$ ) at location 2 (Table 4). 


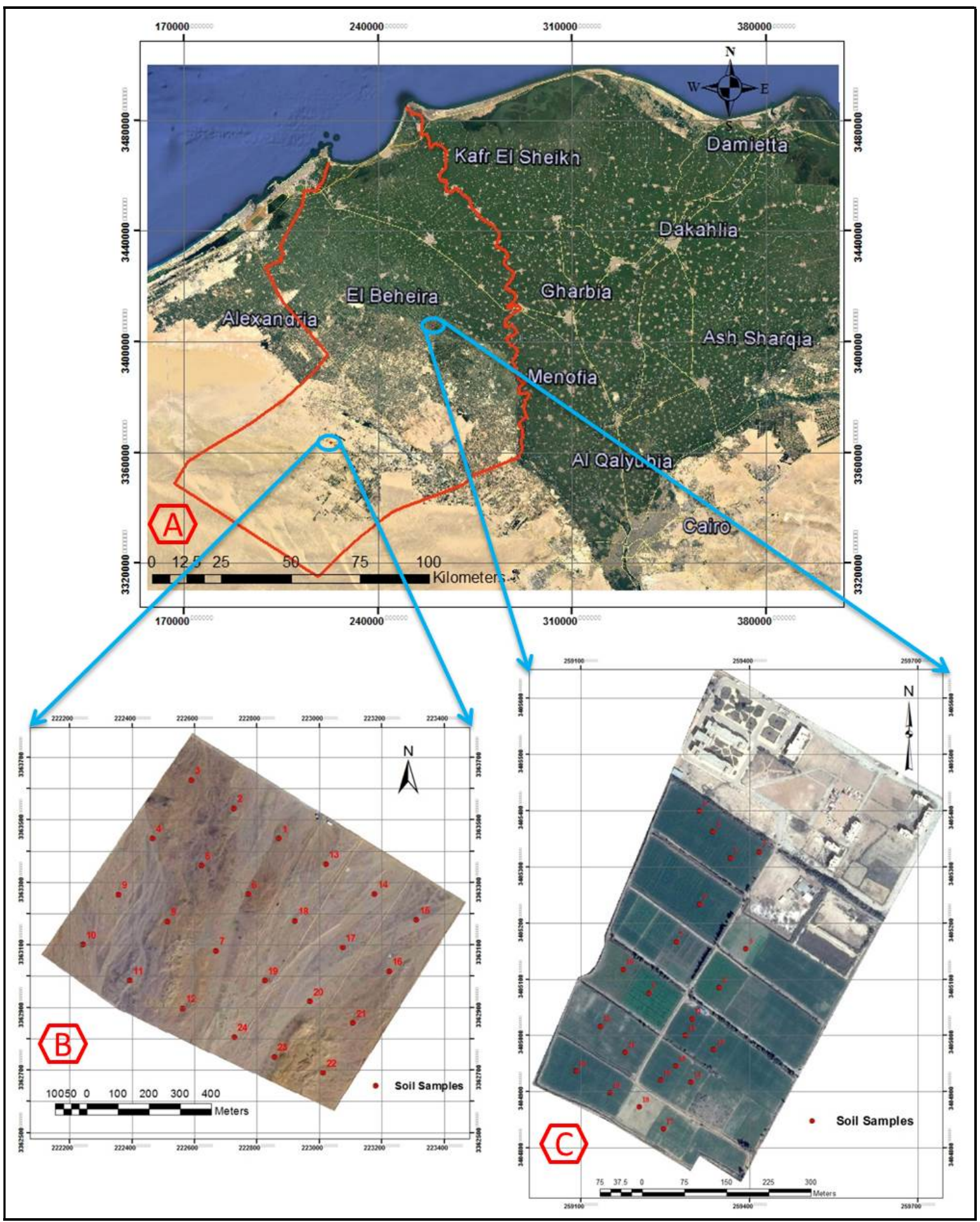

Fig. 1. The distribution of the sample points over the two locations in the study area: A) El-Beheira governorate; B) Wadi-El-Natroun (bare soil); C) El-Bostan (cultivated soil) 


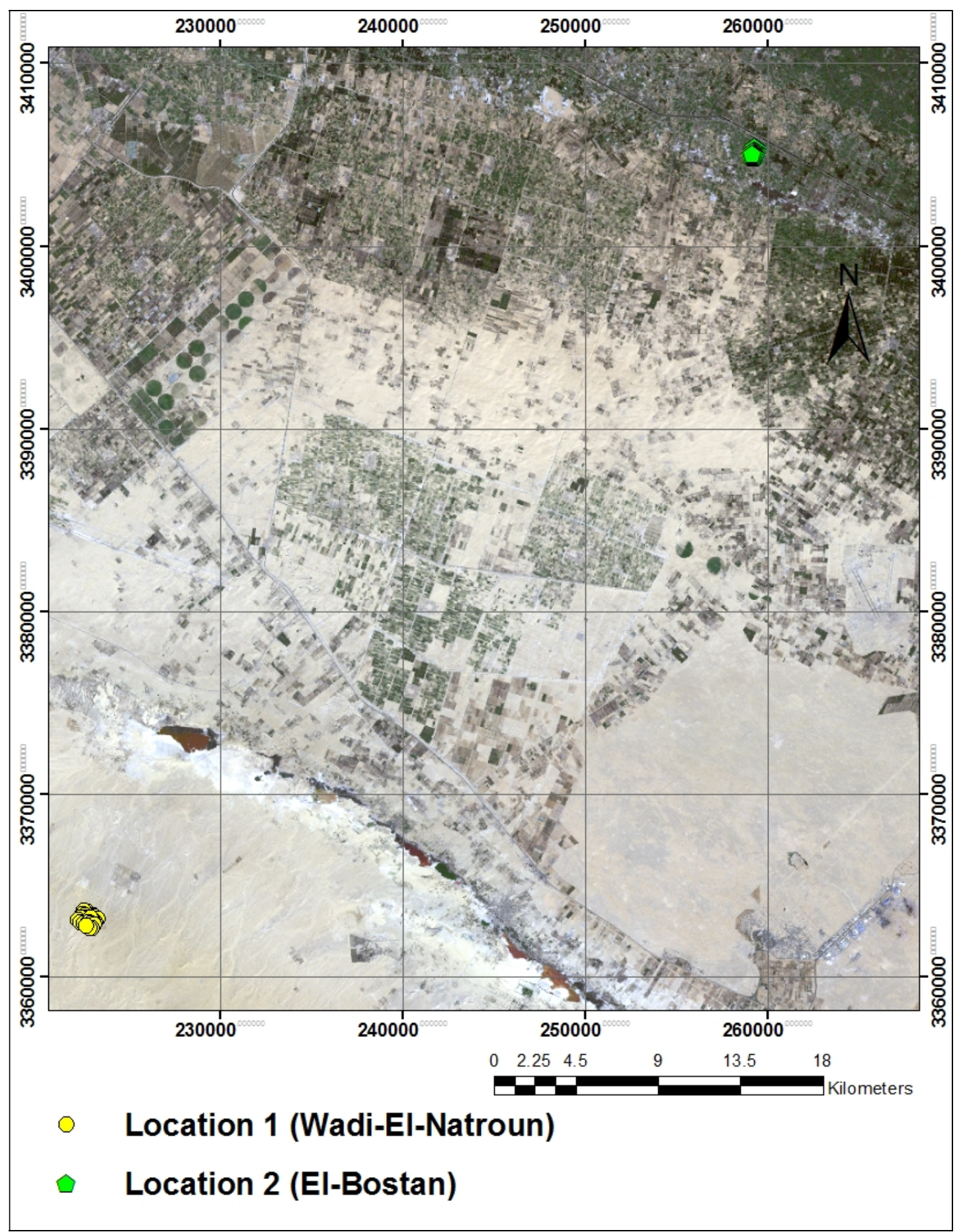

Fig. 2. RGB Landsat 7 (ETM+) image of the study area. 
Table 1. The coordinates of soil samples

\begin{tabular}{lcccc}
\hline \multirow{2}{*}{ Sample No. } & \multicolumn{2}{c}{ Location 1 } & \multicolumn{2}{c}{ Location 2 } \\
\cline { 2 - 5 } & $\mathbf{E}$ & $\mathbf{N}$ & $\mathbf{E}$ & $\mathbf{N}$ \\
\cline { 2 - 5 } 1 & 222879 & 3363440 & 259368 & 3405316 \\
2 & 222738 & 3363529 & 259419 & 3405327 \\
3 & 222583 & 3363628 & 259337 & 3405363 \\
4 & 222479 & 3363445 & 259312 & 3405400 \\
5 & 222623 & 3363348 & 259312 & 3405234 \\
6 & 222780 & 3363258 & 259395 & 3405155 \\
7 & 222675 & 3363081 & 259271 & 3405167 \\
8 & 222521 & 3363172 & 259348 & 3405086 \\
9 & 222356 & 3363266 & 259222 & 3405076 \\
10 & 222245 & 3363094 & 259177 & 3405118 \\
11 & 222405 & 3362989 & 259299 & 3405030 \\
12 & 222573 & 3362897 & 259287 & 3405000 \\
13 & 223077 & 3363384 & 259338 & 3404975 \\
14 & 223127 & 3363275 & 259297 & 3404917 \\
15 & 223324 & 3363175 & 259270 & 3404946 \\
16 & 223228 & 3363016 & 259243 & 3404921 \\
17 & 223055 & 3363067 & 259248 & 3404834 \\
18 & 222930 & 3363240 & 259205 & 3404873 \\
19 & 222834 & 3362991 & 259153 & 3404898 \\
20 & 222971 & 3362955 & 259092 & 3404937 \\
21 & 223113 & 3362847 & 259180 & 3404970 \\
22 & 223011 & 3362662 & 259136 & 3405017 \\
24 & 222871 & 3362697 & & \\
\hline
\end{tabular}

Table 2. Applied spectral indices on the investigated area

\begin{tabular}{clll}
\hline No. & \multicolumn{1}{c}{ Index } & \multicolumn{1}{c}{ Equation } & \multicolumn{1}{c}{ Reference } \\
\hline 1 & Normalized Differential Vegetation Index & NDVI $=(\mathrm{NIR}-\mathrm{R}) /(\mathrm{NIR}+\mathrm{R})$ & Deering and Rouse, 1975 \\
2 & Enhanced Vegetation Index & $\mathrm{EVI}=2.5(\mathrm{NIR}-\mathrm{R}) /(\mathrm{NIR}+6 \mathrm{R}-7.5 \mathrm{~B}+1)$ & Liu and Huete, 1995 \\
3 & Soil Adjusted Vegetation Index & $\mathrm{SAVI}=(\mathrm{NIR}-\mathrm{R}) /(\mathrm{NIR}+\mathrm{R}+\mathrm{L}) *(1+\mathrm{L})$ & Huete, 1988 \\
4 & Ratio Vegetation Index & $\mathrm{RVI}=\mathrm{NIR} / \mathrm{R}$ & Major et al., 1990 \\
5 & Salinity Index & $\mathrm{SI}=\sqrt{ }(\mathrm{B} * \mathrm{R})$ & Khan et al., 2005 \\
6 & Salinity Index 1 & $\mathrm{SI}=\sqrt{ }(\mathrm{G} * \mathrm{R})$ & Khan et al., 2005 \\
7 & Salinity Index 3 & $\mathrm{SI} 3=\sqrt{\left(\left(\mathrm{G}^{\wedge} 2+\mathrm{R}^{\wedge} 2\right)\right)}$ & Douaoui et al., 2006 \\
8 & Salinity Index & $\mathrm{S} 1=\mathrm{B} / \mathrm{R}$ & Bannari et al., 2008 \\
9 & Salinity Index & $\mathrm{S} 2=(\mathrm{B}-\mathrm{R}) /(\mathrm{B}+\mathrm{R})$ & Bannari et al., 2008 \\
10 & Salinity Index & $\mathrm{S} 3=\left(\mathrm{G}^{*} \mathrm{R}\right) / \mathrm{B}$ & Bannari et al., 2008 \\
11 & Salinity Index & $\mathrm{S} 6=(\mathrm{R} * \mathrm{NIR}) / \mathrm{G}$ & Abbas and Khan, 2007 \\
\hline
\end{tabular}

* B, G, R, NIR: reflectance in the blue, green, red and near-infrared bands; $L$ is a constant equal to 0.5 . 
Table 3. Food and Agriculture Organization (FAO) soil salinity classification system.

\begin{tabular}{|c|c|c|c|c|c|c|c|}
\hline EC value & $0-2$ & $2-4$ & \multirow{2}{*}{\multicolumn{2}{|c|}{$\frac{4-8}{\text { moderately saline }}$}} & $8-16$ & \multicolumn{2}{|c|}{$>16$} \\
\hline Salinity class & non-saline & slightly saline & & & strongly saline & \multicolumn{2}{|c|}{ very strongly saline } \\
\hline \multicolumn{8}{|c|}{ Table 4. The laboratory values of EC in the study area. } \\
\hline Sample No. & $\begin{array}{c}E C \\
\mathrm{dS} \mathrm{m}^{-1}\end{array}$ & Sample No. & $\begin{array}{c}E C \\
d_{S} \text { m }^{-1}\end{array}$ & Sample No. & $\begin{array}{c}\text { EC } \\
\mathrm{dS} \mathrm{m}^{-1}\end{array}$ & Sample No. & $\begin{array}{c}\text { EC } \\
\text { dS m } \text { m }^{-1}\end{array}$ \\
\hline 1 & 2.42 & 13 & 1.36 & 1 & 1.00 & 13 & 3.36 \\
\hline 2 & 2.91 & 14 & 1.39 & 2 & 5.23 & 14 & 1.74 \\
\hline 3 & 2.84 & 15 & 3.64 & 3 & 2.96 & 15 & 2.03 \\
\hline 4 & 3.26 & 16 & 8.50 & 4 & 4.32 & 16 & 3.27 \\
\hline 5 & 1.85 & 17 & 3.38 & 5 & 3.60 & 17 & 3.00 \\
\hline 6 & 2.83 & 18 & 3.96 & 6 & 2.73 & 18 & 2.46 \\
\hline 7 & 2.68 & 19 & 1.70 & 7 & 4.40 & 19 & 2.35 \\
\hline 8 & 3.96 & 20 & 1.11 & 8 & 3.86 & 20 & 3.19 \\
\hline 9 & 1.43 & 21 & 1.51 & 9 & 3.42 & 21 & 4.19 \\
\hline 10 & 3.52 & 22 & 9.50 & 10 & 3.57 & 22 & 6.38 \\
\hline 11 & 4.11 & 23 & 4.00 & 11 & 5.48 & & \\
\hline 12 & 4.94 & 24 & 3.58 & 12 & 3.80 & & \\
\hline
\end{tabular}

Soil spectral reflectance

In this part of the research we discuss the soil spectral behavior of different levels of soil salinity depending on the spectral regions provided by the $\mathrm{ETM}+$ data (visible and near-infrared).

There is a high correlation between soil spectral reflectance and its properties such as soil salinity. The spectral reflectance of soil samples was investigated over the visible and NIR wavelength ranges. Spectral reflectance increased as soil salinity increased in bare soil (location 1), whereas, the strongly saline soil evidences higher reflectance than moderately saline soil and the last one reflects a higher amount of radiation than non-saline soil as shown in Fig. 3 and as the studies of Rao et al. (1995); Karavanova et al. (2001) and Metternicht and Zinck (2003) revealed. On the other hand, at the cultivated soils (location 2), Spectral reflectance decreased as soil salinity increased except over the blue band (Fig. 3).

However, the visible and NIR reflectance is a good indicator for soil salinity, whereas it is displaying more sensitivity to its levels. Those findings agree with those of Schmid et al. (2008) and Bouaziz et al. (2011). According to the results in this study area and as shown in Fig. 3, high EC value gives a relatively higher spectral response in the NIR than in the visible spectrum.

\section{Remote sensing spectral indices}

Essentially, we use two approaches to detect soil salinity by remote sensing; the first approach is direct by analyzing the spectral reflectance of soils (bare soils) and the second one is indirect through analyzing the spectral reflectance of growing vegetation on soils (Mashimbye, 2013).

There was a good relationship between EC and all of salinity indices in location 1, but the best relationship was found with SI3, S6 and S3 indices, respectively (Table 5). However, all vegetation indices were not significant and the SAVI was the poorest predictor of soil salinity at this location.

This finding concurs with the results acquired by Bouaziz et al. (2011) and Fan et al. (2012) who found that the vegetation indices were weakly correlated with EC values, while the soil salinity indices were more strongly correlated with bare soil.

We could use the vegetation performance in the cultivated soil as an indirect indicator to soil salinity (Wang et al., 2013), whereas we assume that a large vegetation amount means more successful crop growth and less harmful salts in the soil. There was a good relationship between EC and all of vegetation indices at location 2 except EVI index. The best relationship was with NDVI and SAVI indices (the same values), followed by RVI (Table 5). However, all salinity indices were not significant. Among all of the assessed indices, EVI yielded poor findings for assessing soil salinity at this location.

Polynomial and linear regression results for different spectral indices are presented in Fig. 4 and Fig. 5. Salinity index (SI3) indicated the best result with $\mathrm{R}^{2}$ value 0.77 for the linear regression analysis, and (S6) for the polynomial regression with $\mathrm{R}^{2}$ value 0.83 for location 1.

On the other hand, the NDVI and SAVI were the best indices with $\mathrm{R}^{2}$ value 0.83 and 0.76 for the 
polynomial and linear regression analysis, respectively, for location 2. Our results are similar to those of Alhammadi and Glenn (2008) and Allbed et al. (2014) who reported that the SAVI index gave very good results with assessing soil salinity of cultivated soils. The equations shown in Fig. 4 and Fig. 5 could be used to predict soil salinity by using spectral indices without direct EC measurements.

Table 5. The relationships between the selected spectral indices and the EC

\begin{tabular}{cccccc}
\hline \multirow{2}{*}{ No. } & Spectral & \multicolumn{2}{c}{ Location 1 } & \multicolumn{2}{c}{ Location 2 } \\
\cline { 3 - 6 } & Indices & $\begin{array}{c}\mathbf{R}^{\mathbf{2}} \\
\text { (Linear Regression) }\end{array}$ & $\begin{array}{c}\mathbf{R}^{\mathbf{2}} \\
\text { Polynomial Regression) }\end{array}$ & $\begin{array}{c}\mathbf{R}^{\mathbf{2}} \\
\text { (Linear Regression) }\end{array}$ & $\begin{array}{c}\mathbf{R}^{\mathbf{2}} \\
\text { (Polynomial Regression) }\end{array}$ \\
\hline 1 & NDVI & 0.24 & 0.32 & 0.76 & 0.83 \\
2 & EVI & 0.28 & 0.41 & 0.00 & 0.01 \\
3 & RVI & 0.24 & 0.33 & 0.68 & 0.82 \\
4 & SAVI & 0.24 & 0.32 & 0.76 & 0.83 \\
5 & SI & 0.61 & 0.67 & 0.05 & 0.50 \\
6 & SI1 & 0.64 & 0.71 & 0.14 & 0.52 \\
7 & SI3 & 0.77 & 0.82 & 0.01 & 0.44 \\
8 & S1 & 0.52 & 0.64 & 0.47 & 0.58 \\
9 & S2 & 0.53 & 0.64 & 0.48 & 0.58 \\
10 & S3 & 0.74 & 0.82 & 0.00 & 0.25 \\
11 & S6 & 0.76 & 0.83 & 0.23 & 0.57 \\
\hline
\end{tabular}

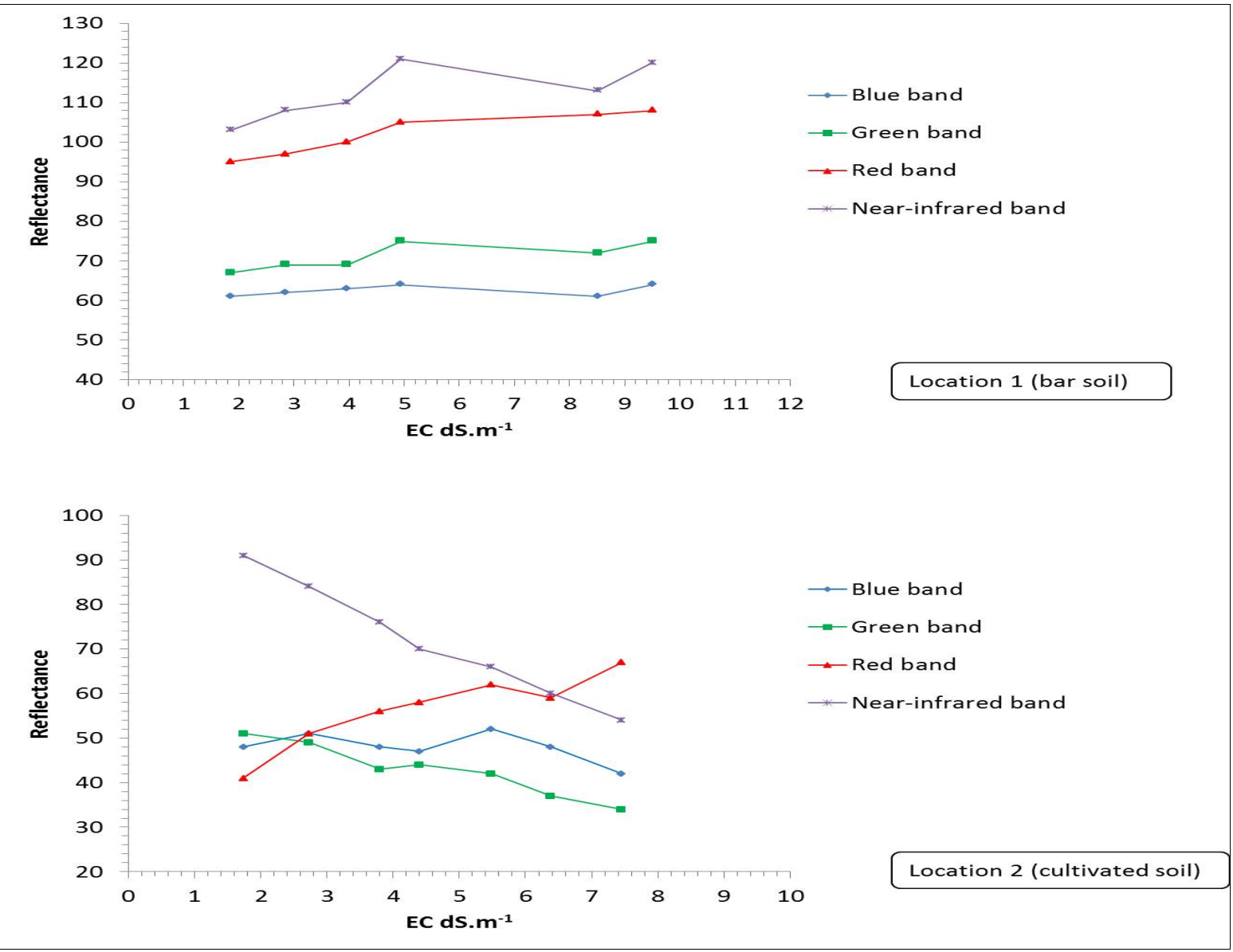

Fig. 3. Spectral signature variation of different soil surface features due to differences in electrical conductivity 


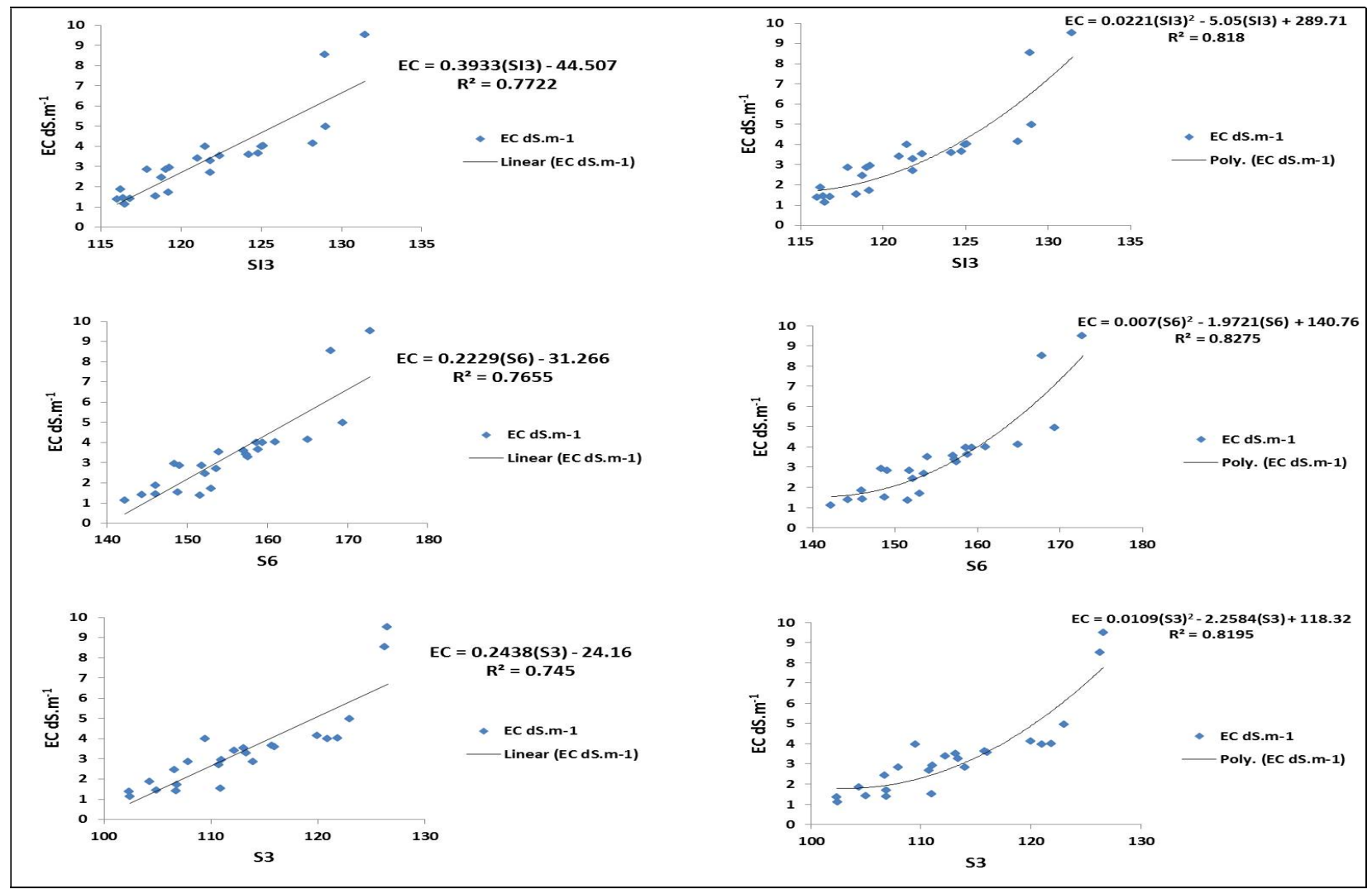

Fig. 4. Regression equation relating EC and some salinity indices at location 1.

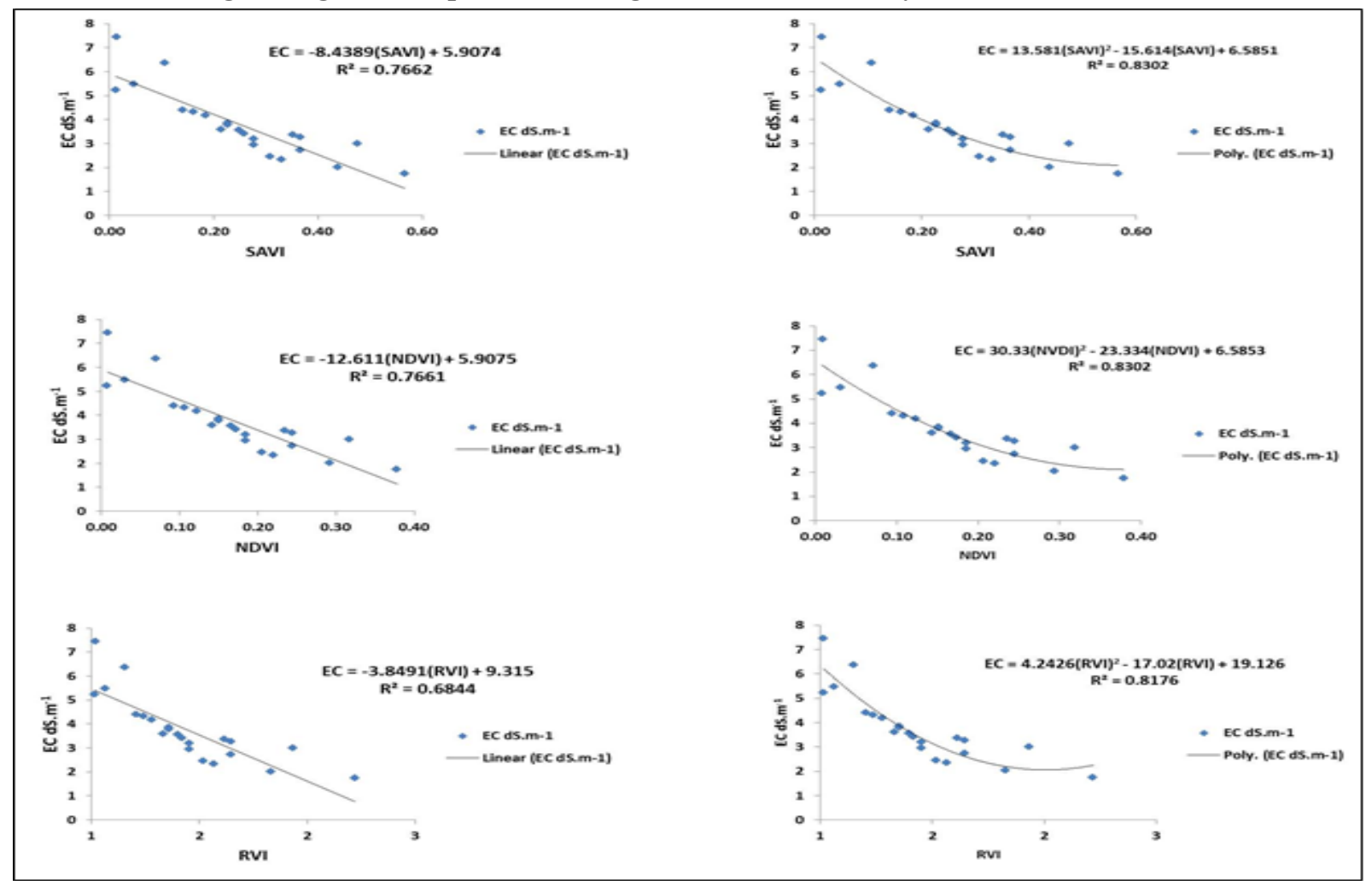

Fig. 5. Regression equation relating $\mathrm{EC}$ and some vegetation indices at location 2 


\section{CONCLUSION}

In arid and semi-arid regions of the world, soil salinization is a major factor that affects agricultural productivity and sustainable development. The monitoring and predicting of soil salinity are very important to take protective measures against further soil degradation. Remote sensing considered as a particularly valuable tool for achieving this task. This research focused on the spectral indices (salinity and vegetation indices) for the prediction of soil salinity in bare and cultivated lands in El-Beheira governorate, Egypt. The results show that: Overall, the salinity indices that were extracted from the ETM+ satellite images were the most useful for assessing the soil salinity in bare areas and the vegetation indices for cultivated areas.

The results of this study showed that the SI3, S6 and S3indices were the most useful for assessing soil salinity in the bare areas. Whereas NDVI, SAVI and RVI yield better outcomes for the cultivated areas, respectively. Those indices are useful indicators for soil salinity prediction in the study area. However, it may be unsuited for other regions as their performance varies with different environmental conditions, soil, and vegetation cover, etc. Those indices may help decisionmakers and land planners to face the salinity issue at a regional level and avoid further adverse environmental effects.

\section{ACKNOWLEDGMENT}

We thank the college of Agricultural, Damanhour University, Egypt for funding this research

\section{REFERENCES}

Abbas, A., Khan, S., 2007. Using remote sensing techniques for appraisal of irrigated soil salinity. Paper presented at the Advances and Applications for Management and Decision Making Land, Water and Environmental Management: Integrated Systems for Sustainability MODSIM07.

Abrol I., J.S.P. Yadav, and F. Massoud. 1988. Salt-affected soils and their management, vol. 39. Food \& Agriculture Org.

Aldakheel Y.Y. 2011. Assessing NDVI Spatial Pattern as Related to Irrigation and Soil Salinity Management in AlHassa Oasis, Saudi Arabia, Journal of the Indian Society of Remote Sensing, Vol. 39, No. 2, 2011, pp. 171-180. http://dx.doi.org/10.1007/s12524-010-0057-z

Alhammadi M.S., and E.P. Glenn. 2008. Detecting date palm trees health and vegetation greenness change on the eastern coast of the united arab emirates using SAVI. Int. J. Remote Sens. 29, 1745-1765.
Al-Khair F. 2003. Soil salinity detection using satellite remote sensing. Master of Science in Geo-information science and earth observation. International Institute for Geoinformation science and earth observation, Netherlands.

Allbed A., L. Kumar, and Y. Aldakheel. 2014. Assessing soil salinity using soil salinity and vegetation indices derived from IKONOS high-spatial resolution imageries: Applications in a date palm dominated region. Geoderma 230-231, 1-8.

ArcMap 10.2 2008 ESRI, Environmental Systems Research Institute. U.S. copyright 2008 ESRI Inc.

Bannari, A., Guedon, A.M., El-Harti, A., Cherkaoui, F.Z., ElGhmari, A., 2008. Characterization of slightly and moderately saline and sodic soils in irrigated agricultural land using simulated data of advanced land imaging (EO1) sensor. Communications in Soil Science and Plant Analysis 39 (19), 2795-2811.

Bouaziz M., J. Matschullat, and R. Gloaguen. 2011. Improved remote sensing detection of soil salinity from a semi-arid climate in Northeast Brazil. Compt. Rendus Geosci. 343 (11-12), 795-803.

Deering, D. W., Rouse, J. W., Haas, R. H., and Schell, J. A. 1975, Measuring" forage production" of grazing units from Landsat MSS data, Proceedings of the 10th International Symposium Remote Sensing of Environment, Vol. II, pp. 1169-1178

Douaoui A E K, Nicolas H, Walter C. 2006. Detecting salinity hazards within a semiarid context by means of combining soil and remote-sensing data. Geoderma, 134(1-2): 217230.

Ebaid H.M., H.A. Farag, and A.A. El-Falaky. 2016. Using GIS and Remote Sensing Approaches to Delineate Potential Areas for Runoff Management Applications in Egypt. International Journal of Environmental Science and Engineering (IJESE) Vol. 7: 85- 93.

ENVI 5.3 2008 Environment for Visualizing Image, version 4.5. ITT Visual Information Solutions. www.ittvis.com.

ERDAS 8.4 1999 ERDAS IMAGINE, version 8.4. ERDAS Inc., USA, 1999.

Fan X., B. Pedroli, G. Liu, Q. Liu, H. Liu, and L. Shu. 2012. Soil salinity development in the Yellow River Delta in relation to groundwater dynamics. Land Degrad. Dev. 23 (2), 175-189.

FAO, 2002. The salt of the earth: hazardous for food production. Available

at: http:/www.fao.org/worldfoodsummit/english/newsroom/f ocus/focus1.htm (accessed at 19 February 2015)

Farifteh J. 2007. Imaging spectroscopy of salt-affected soils: Model-based integrated method. PhD thesis, International Institute for Geo-Information Science and Earth Observation, and Utrecht University, Netherlands.

Gehad A. 2003. Deteriorated Soils in Egypt: Management and Rehabilitation. Executive Authority for Land Improvement Projects (EALIP) - Egypt. 
Gorji T., E. Sertel, and A. Tanik. 2017. Monitoring soil salinity via remote sensing technology under data scarce conditions: A case study from Turkey. Ecological Indicators 74 (2017) 384-391.

Gorji T., A. Tanik, and E. Sertel. 2015. Soil salinity prediction, monitoring and mapping using modern technologies. Procedia erath and planetary science $15-$ 507-512.

Huete, A.R., 1988. A soil adjusted vegetation index (SAVI). Remote Sens. Environ. 25, 295-309.

Jackson M. L. 1973. Soil chemical analysis. Prentice-Hall of India private limited, New Delhi, 498 pp

Karavanova E. I., D. P. Shrestha, and D. S. Orlov. 2001. Application of remote sensing techniques for the study of soil salinity in semi-arid Uzbekistan. In: Bridges, E.M., Hannam, I.D., Oldeman, L.R., de Vries, F.T.P., Scherr, S.J., Sombatpanit, S. (Eds.), Responses to Land Degradation. Oxford and IBH Publishing Co. Pvt. Ltd., New Delhi, pp. 261-273.

Katawatin R., and W. Kotrapat. 2004. "Use of LANDSAT-7 ETM+ with Ancillary Data for Soil Salinity Mapping in Northeast Thailand," Third International Conference on Experimental Mechanics and Third Conference of the Asian, Sevilla, 3 June 2005, pp. 708-716.

Khan N M, Rastoskuev V V, Sato Y, et al. 2005. Assessment of hydrosaline land degradation by using a simple approach of remote sensing indicators. Agricultural Water Management, 77(1-3): 96-109.

Koohafkan P. 2012. Water and Cereals in Drylands, the Food and Agriculture Organization of the United Nations and Earthscan, Rome.

Liu H.Q., Huete A.R. A feedback based modification of the NDV I to minimize canopy background and atmospheric noise. IEEE Transactions on Geoscience and Remote Sensing. 1995; 33:457-465.

Major, D. J., Baret, F. and Guyot, G. 1990 A ratio vegetation index adjusted for soil brightness. International Journal of Remote Sensing 11 (5): 727-740.

Koohafkan P. 2012. Water and Cereals in Drylands, the Food and Agriculture Organization of the United Nations and Earthscan, Rome.

Mashimbye Z.E. 2013. Remote sensing of salt-affected soils. Dissertation presented for the degree Doctor of Philosophy in the Faculty of AgriSciences at Stellenbosch University

Matinfar H.R. 2013. Detection of Soil Salinity Changes and Mapping Land Cover Types Based upon Remotely Sensed Data. Arabian Journal of Geosciences, Vol. 6, No. 3, 2013, pp. 913-919.

Mehrjardi R. T., S. H. Mahmoodi, M. Taze, and E. Sahebjalal. 2008. "Accuracy Assessment of Soil Salinity Map in Yazd-Ardakan Plain, Central Iran, Based on Land sat ETM+ Imagery," American-Eurasian Journal of Agricultural \& Environmental Sciences, Vol. 3, No. 5, pp. 708-712.
Metternicht G. I., and J. A. Zinck. 2003. Remote sensing of soil salinity: potentials and constraints. Remote Sensing of Environment 85, 1-20 http://en.wikiversity.org/wiki/Multiple_linear_regression.

Mulder V. L., S. Bruin, M. E. Schaepman, and T. R. Mayr. 2011. The use of remote sensing in soil and terrain mapping-A review. Geoderma 2011, 162, 1-19.

Rao B.R.M., R.C. Sharma, T.R. Sankar, S.N. Das, R.S. Dwivedi, S.S. Thammappa, and L. Venkataratnam. 1995. Spectral behaviour of salt-affected soils. Int. J. Remote Sensing. 16 (12), 2125-2136.

Rhoades J.D. 1990. Soil salinity - causes and controls. In techniques for desert reclamation, School of Geography University of Oxford.

Rowell D.L. 1994. Soils Science: Methods and applications. London: Prince Hall.

Schmid T., M. Koch, and J. Gumuzzio. 2008. Applications of hyperspectral imagery to soil salinity mapping. In: Metternicht, G., Zaid, J.A. (Eds.), Remote Sensing of Soil Salinization: Impact on Land Management. CRC Press, Taylor and Francis, New York, pp. 113-137.

SPSS. 2007. Statistical Package for Social Sciences base 16.0 user's guide. SPSS Inc., Chicago

Varallyay G. 1987. Conclusions on symposium: soil structure in fully mechanized cropping systems. Trans. XIII Congr. of the I.S.S.S., 13-20 August 1986. Symposia papers. Vol. V, 328-329, Hamburg.

Wang F., X. Chen, G. Luo, J. Ding, and X. Chen. 2013. Detecting soil salinity with arid fraction integrated index and salinity index in feature space using Landsat TM imagery. J Arid Land, 5(3): 340-353

Yu R., T.X. Liu, Y. P. Xu, C. Zhu, Q. Zhang, Z.Y. Qu, X.M. Liu, and C.Y. Li. 2010. Analysis of Salinization Dynamics by Remote Sensing in Hetao Irrigation District of North China, Agricultural Water Management, Vol. 97, No. 12, 2010, pp. 1952-1960. http://dx.doi.org/10.1016/j.agwat.2010.03.009

Abbas, A., Khan, S., 2007. Using remote sensing techniques for appraisal of irrigated soil salinity. Paper presented at the Advances and Applications for Management and Decision Making Land, Water and Environmental Management: Integrated Systems for Sustainability MODSIM07.

Abrol I., J.S.P. Yadav, and F. Massoud. 1988. Salt-affected soils and their management, vol. 39. Food \& Agriculture Org.

Aldakheel Y.Y. 2011. Assessing NDVI Spatial Pattern as Related to Irrigation and Soil Salinity Management in AlHassa Oasis, Saudi Arabia, Journal of the Indian Society of Remote Sensing, Vol. 39, No. 2, 2011, pp. 171-180. http://dx.doi.org/10.1007/s12524-010-0057-z

Alhammadi M.S., and E.P. Glenn. 2008. Detecting date palm trees health and vegetation greenness change on the eastern coast of the united arab emirates using SAVI. Int. J. Remote Sens. 29, 1745-1765. 
Al-Khair F. 2003. Soil salinity detection using satellite remote sensing. Master of Science in Geo-information science and earth observation. International Institute for Geoinformation science and earth observation, Netherlands.

Allbed A., L. Kumar, and Y. Aldakheel. 2014. Assessing soil salinity using soil salinity and vegetation indices derived from IKONOS high-spatial resolution imageries: Applications in a date palm dominated region. Geoderma 230-231, 1-8.

ArcMap 10.2 2008 ESRI, Environmental Systems Research Institute. U.S. copyright 2008 ESRI Inc.

Bannari, A., Guedon, A.M., El-Harti, A., Cherkaoui, F.Z., ElGhmari, A., 2008. Characterization of slightly and moderately saline and sodic soils in irrigated agricultural land using simulated data of advanced land imaging (EO1) sensor. Communications in Soil Science and Plant Analysis 39 (19), 2795-2811.

Bouaziz M., J. Matschullat, and R. Gloaguen. 2011. Improved remote sensing detection of soil salinity from a semi-arid climate in Northeast Brazil. Compt. Rendus Geosci. 343 (11-12), 795-803.

Deering, D. W., Rouse, J. W., Haas, R. H., and Schell, J. A. 1975, Measuring" forage production" of grazing units from Landsat MSS data, Proceedings of the 10th International Symposium Remote Sensing of Environment, Vol. II, pp. 1169-1178

Douaoui A E K, Nicolas H, Walter C. 2006. Detecting salinity hazards within a semiarid context by means of combining soil and remote-sensing data. Geoderma, 134(1-2): 217230 .

Ebaid H.M., H.A. Farag, and A.A. El-Falaky. 2016. Using GIS and Remote Sensing Approaches to Delineate Potential Areas for Runoff Management Applications in Egypt. International Journal of Environmental Science and Engineering (IJESE) Vol. 7: 85- 93.

ENVI 5.3 2008 Environment for Visualizing Image, version 4.5. ITT Visual Information Solutions. www.ittvis.com.

ERDAS 8.4 1999 ERDAS IMAGINE, version 8.4. ERDAS Inc., USA, 1999.

Fan X., B. Pedroli, G. Liu, Q. Liu, H. Liu, and L. Shu. 2012. Soil salinity development in the Yellow River Delta in relation to groundwater dynamics. Land Degrad. Dev. 23 (2), 175-189.

FAO, 2002. The salt of the earth: hazardous for food production. Available at: http://www.fao.org/worldfoodsummit/english/newsroom/f ocus/focus1.htm (accessed at 19 February 2015)

Farifteh J. 2007. Imaging spectroscopy of salt-affected soils: Model-based integrated method. PhD thesis, International Institute for Geo-Information Science and Earth Observation, and Utrecht University, Netherlands.

Gehad A. 2003. Deteriorated Soils in Egypt: Management and Rehabilitation. Executive Authority for Land Improvement Projects (EALIP) - Egypt.
Gorji T., E. Sertel, and A. Tanik. 2017. Monitoring soil salinity via remote sensing technology under data scarce conditions: A case study from Turkey. Ecological Indicators 74 (2017) 384-391.

Gorji T., A. Tanik, and E. Sertel. 2015. Soil salinity prediction, monitoring and mapping using modern technologies. Procedia erath and planetary science $15-$ 507-512.

Huete, A.R., 1988. A soil adjusted vegetation index (SAVI). Remote Sens. Environ. 25, 295-309.

Jackson M. L. 1973. Soil chemical analysis. Prentice-Hall of India private limited, New Delhi, $498 \mathrm{pp}$

Karavanova E. I., D. P. Shrestha, and D. S. Orlov. 2001. Application of remote sensing techniques for the study of soil salinity in semi-arid Uzbekistan. In: Bridges, E.M., Hannam, I.D., Oldeman, L.R., de Vries, F.T.P., Scherr, S.J., Sombatpanit, S. (Eds.), Responses to Land Degradation. Oxford and IBH Publishing Co. Pvt. Ltd., New Delhi, pp. 261-273.

Katawatin R., and W. Kotrapat. 2004. "Use of LANDSAT-7 ETM+ with Ancillary Data for Soil Salinity Mapping in Northeast Thailand," Third International Conference on Experimental Mechanics and Third Conference of the Asian, Sevilla, 3 June 2005, pp. 708-716.

Khan N M, Rastoskuev V V, Sato Y, et al. 2005. Assessment of hydrosaline land degradation by using a simple approach of remote sensing indicators. Agricultural Water Management, 77(1-3): 96-109.

Koohafkan P. 2012. Water and Cereals in Drylands, the Food and Agriculture Organization of the United Nations and Earthscan, Rome.

Liu H.Q., Huete A.R. A feedback based modification of the NDV I to minimize canopy background and atmospheric noise. IEEE Transactions on Geoscience and Remote Sensing. 1995; 33:457-465.

Major, D. J., Baret, F. and Guyot, G. 1990 A ratio vegetation index adjusted for soil brightness. International Journal of Remote Sensing 11 (5): 727-740.

Koohafkan P. 2012. Water and Cereals in Drylands, the Food and Agriculture Organization of the United Nations and Earthscan, Rome.

Mashimbye Z.E. 2013. Remote sensing of salt-affected soils. Dissertation presented for the degree Doctor of Philosophy in the Faculty of AgriSciences at Stellenbosch University

Matinfar H.R. 2013. Detection of Soil Salinity Changes and Mapping Land Cover Types Based upon Remotely Sensed Data. Arabian Journal of Geosciences, Vol. 6, No. 3, 2013, pp. 913-919.

Mehrjardi R. T., S. H. Mahmoodi, M. Taze, and E. Sahebjalal. 2008. "Accuracy Assessment of Soil Salinity Map in Yazd-Ardakan Plain, Central Iran, Based on Land sat ETM+ Imagery," American-Eurasian Journal of Agricultural \& Environmental Sciences, Vol. 3, No. 5, pp. 708-712. 
Metternicht G. I., and J. A. Zinck. 2003. Remote sensing of soil salinity: potentials and constraints. Remote Sensing of Environment 85 , http://en.wikiversity.org/wiki/Multiple linear_regression.

Mulder V. L., S. Bruin, M. E. Schaepman, and T. R. Mayr. 2011. The use of remote sensing in soil and terrain mapping-A review. Geoderma 2011, 162, 1-19.

Rao B.R.M., R.C. Sharma, T.R. Sankar, S.N. Das, R.S. Dwivedi, S.S. Thammappa, and L. Venkataratnam. 1995. Spectral behaviour of salt-affected soils. Int. J. Remote Sensing. 16 (12), 2125-2136.

Rhoades J.D. 1990. Soil salinity - causes and controls. In techniques for desert reclamation, School of Geography University of Oxford.

Rowell D.L. 1994. Soils Science: Methods and applications. London: Prince Hall.
Schmid T., M. Koch, and J. Gumuzzio. 2008. Applications of hyperspectral imagery to soil salinity mapping. In: Metternicht, G., Zaid, J.A. (Eds.), Remote Sensing of Soil Salinization: Impact on Land Management. CRC Press, Taylor and Francis, New York, pp. 113-137.

SPSS. 2007. Statistical Package for Social Sciences base 16.0 user's guide. SPSS Inc., Chicago

Varallyay G. 1987. Conclusions on symposium: soil structure in fully mechanized cropping systems. Trans. XIII Congr. of the I.S.S.S., 13-20 August 1986. Symposia papers. Vol. V, 328-329, Hamburg.

Wang F., X. Chen, G. Luo, J. Ding, and X. Chen. 2013. Detecting soil salinity with arid fraction integrated index and salinity index in feature space using Landsat TM imagery. J Arid Land, 5(3): 340-353

Yu R., T.X. Liu, Y. P. Xu, C. Zhu, Q. Zhang, Z.Y. Qu, X.M. Liu, and C.Y. Li. 2010. Analysis of Salinization Dynamics by Remote Sensing in Hetao Irrigation District of North China, Agricultural Water Management, Vol. 97, No. 12, 2010, pp. 1952-1960.

\section{الملخص العربي}

\section{الكثف عن ملوحة التربة للأراضي الغير مزروعة والمزروعة باستخدام بيانات صور القمر الصناعي

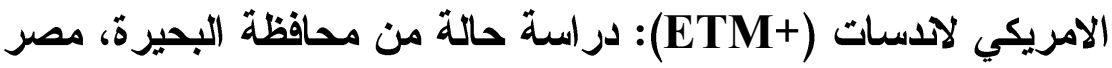

\author{
عماد فوزى عبد العاطى، عماد فاروق أبوكيله
}

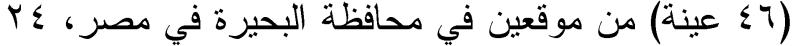
عينة من و ادي النطرون (التربة الغير مزروعة) و r r عينة من البستان (التربة المزروعة) وتم توقيع أماكن عينات التربة على صورة القمر الصناعي لاستخراج قيم الأدلة

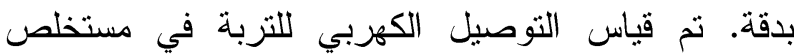
عجينة التربة المشبعة للطبقة السطحية بعمق •ـ سم، و أظهرت النتائج أن مؤشر الملوحة (SI3) أعطى أعلي قيمة انحدار مع التوصيل الكهربائي مع تحليل الانحدار المتعدد (Polynomial) كان معامل الانحدار لهذا الدليل (R²) هو على التوالي بالنسبة للتربة الغير مزروعة. اما بالنسبة للنزبة المزروعة فقد أعطي دليل الغطاء النباتي (SAVI)

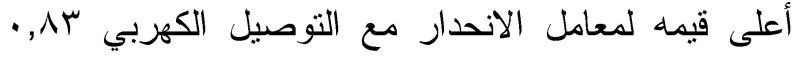
و VT, • وفقا لتحليل الانحدار المتعدد و الخطي على التوالي.
تعتبر ملوحة التزبة من أبرز القضايا البيئية العالمية وذللك بسبب آنارها السلبية على الإنتاجية الزر اعية و التتمية المستدامة، وكذلك يعتبر الاستشعار عن بعد أداة هامة لاستكثاف خصائص التربة مثل الملوحة. يتفاوت الانعكاس الطيفي للأملاح على سطح التربة وكذلك بالنسبة لانعكاسات الغطاء النباتي و الذي يتأثر سلبا بالمستويات المختلفة من الملوحه. لذلك، تم تطوير واستخدام العديد من دلائل الملوحة و الغطاء النباتي حيث استخدمت في هذه الدراسة بيانات أرضية و الانعكاسات الطيفية في مدى الضوء المرئي و الضوء القريب من الأشعة تحت الحمر اء للقمر الصناعي

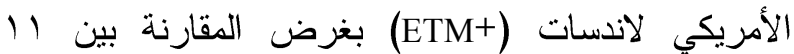
مؤشرا طيفيا، و التي الثتملت على دلائل الملوحة ودلائل الغطاء النباتي لتحديد أفضل مؤشر للتنبؤ بملوحة التربة الغير مزروعة والتربة المزروعة. تم جمع عينات التربة 